\title{
Role of Post-Decompressive Hydrocephalus in Patients with Malignant Cerebral Infarction
}

\author{
Malign Serebral Infarktlı Hastalarda Post-Dekompresif Hidrosefalinin \\ Rolii
}

Bon-Jour LIN, Kuan-Nein CHOU, Shai-Wei FENG, Da-Tong JU, Hsin-I MA, Dueng-Yuan HUENG

Tri-Service General Hospital, National Defense Medical Center, Department of Neurological Surgery, Taipei, Taiwan, R.O.C.

Corresponding Author: Dueng-Yuan HUENG / E-mail: i0719andyou0305@hotmail.com

\begin{abstract}
AIM: The association between post-decompressive hydrocephalus and clinical neurological expression is still unclear. In order to investigate this relationship, the authors analyze series of ventricular morphology and level of consciousness at different clinical stages for patients accepting decompressive craniectomy (DC).

MATERIAL and METHODS: From 2005 to 2011, 13 patients accepting DC under the diagnosis of malignant cerebral infarction were retrospectively evaluated in terms of ventricular frontal horn dilatation and level of consciousness, Glasgow Coma Scale score, at four different clinical stages: 1): pre-DC stage; 2): post-DC stage while stabilization; 3): post-cranioplasty stage; 4): post-shunt stage [for those with permanent cerebrospinal fluid (CSF) diversion].

RESULTS: All 13 patients had ventricular dilatation and two of them had extra-axial CSF collection. Restoration of ventricular dilatation was not observed in all patients after bone flap placement, but extra-axial CSF collection resorbed spontaneously. Four patients accepting permanent CSF diversion had no improvement over neurological expression. Otherwise, two of them complicated with subdural effusion after shunt placement.

CONCLUSION: Decompressive craniectomy itself would lead to ventricular dilatation universally. There is no direct association between degree of ventriculomegaly and neurological expression. Permanent CSF diversion surgery as treatment for ventriculomegaly makes no clinical improvement with possible complications of overshunting.
\end{abstract}

KEYWORDS: Decompressive craniectomy, Hydrocephalus, Ventriculomegaly

öz

AMAÇ: Post-dekompresif hidrosefali ile klinik nörolojik tablo arasındaki ilişki halen tam olarak ortaya konamamıştır. Bu ilişkiyi araştırmak için, yazarlar dekompresif kraniyektomi (DK)'yi kabul eden hastaların değişik klinik evrelerinde ventriküler morfoloji ve bilinç düzeylerini analiz etmişlerdir.

YÖNTEM ve GEREÇLER: 2005-2011 yılları arasında malign serebral infarkt tanısı sonrası DK'yi kabul eden 13 hasta ventriküler frontal horn genişlemesi ve bilinç düzeyi, Glasgow Koma Skalası skoru yönünden 4 farklı evrede retrospektif olarak incelendi. Bu evreler: 1) DK öncesi evre, 2) DK sonrası (stabilizasyon) evre, 3) Kraniyoplasti sonrası evre, 4) Şant sonrası evre [Kalıcı beyin-omurilik sıvısı (BOS) drenajı uygulananlar için]. BULGULAR: On üç hastanın tümünde ventriküler genişleme ve bunların 2 tanesinde ekstra-aksiyel BOS kolleksiyonu vardı. Kemik flep yerleştirildikten sonra ventriküler genişlemede herhangi bir düzelme olmadı, ancak ekstra-aksiyel BOS kolleksiyonu spontan olarak rezorbe oldu. Kalııı BOS drenajını kabul eden 4 hastanın nörolojik tablosunda düzelme olmadı. Hatta, bunların 2 tanesinde şant yerleştirilmesinden sonra subdural effüzyon gelişti.

SONUÇ: Dekompresif kraniyektomi genellikle tek başına ventriküler dilatasyona neden olabilir. Ventrikülomegalinin derecesi ile nörolojik tablo arasında direkt bir bağlantı yoktur. Ventrikülomegalinin tedavisinde kalıcı BOS drenajına yönelik cerrahi yöntemler klinik düzeltme yapmadığı gibi aşırı boşaltma gibi komplikasyonlara da neden olabilir.

ANAHTAR SÖZCÜKLER: Dekompresif kraniyektomi, Hidrosefali, Ventrikülomegali

\section{INTRODUCTION}

Decompressive craniectomy (DC) has been accepted as a therapeutic strategy for patients with medically refractory increased intracranial pressure (ICP) secondary to severe traumatic brain injury (TBI), malignant middle cerebral artery (MCA) or internal cerebral artery (ICA) infarction, large hypertensive intracerebral hemorrhage (ICH), high-grade aneurys- mal subarachnoid hemorrhage and severe cerebral venous sinus thrombosis $(5,7,12,13,14,17,20)$.

The goal of DC is to relieve increased ICP by removing the bone flap to gain additional intracranial volume and improve cerebral perfusion, compliance and oxygenation $(10,16)$. However, the occurrence of complication after DC, including sinking-flap syndrome, hydrocephalus, subdural hygroma and hematoma is not uncommon $(1,2,3,6,21,23)$. 
Up to now, hydrocephalus has gained more and more emphasis among these stated complications due to its potential impact on long-term clinical outcome. Hydrocephalus after DC for patients with severe TBI was reported by several studies previously and several identified risk factors for hydrocephalus development were announced $(4,6,8,9)$. However, the certainty of DC itself as the major cause of hydrocephalus is still questionable due to appearance of variable confounding factors in patients with severe TBI. In recent years, the role of hydrocephalus after DC for patients with malignant MCA/ICA infarction or large hypertensive ICH got being discussed by some studies $(11,15,18,19,21)$. Most of them focused on radiographic finding but not influence on clinical outcome.

In this study, we retrospectively recorded and analyzed series of ventricular morphology and level of consciousness at different clinical stages for patients accepting DC due to malignant MCA/ICA infarction. The purpose of this study is to link the morphological change of ventricle on brain computed tomography (CT) scan after DC and neurological expression to determine its clinical significance.

\section{MATERIAL and METHODS}

\section{Patient Demographics}

From January 2005 to December 2011, 58 patients accepting DC under the diagnosis of MCA/ICA infarction with severe cerebral swelling in our institute were reviewed retrospectively. The exclusion criteria included patients having previous ventriculoperitoneal shunt placement, those accepting bilateral DC, those with acute hydrocephalus while admission, those died within one month postoperatively and those being lost to follow-up before bone flap replacement.

Among 26 patients eligible for further investigation, we excluded patients having risk factors known to be associated with hydrocephalus development such as subarachnoid hemorrhage, intraventricular hemorrhage and intracranial infection. Six patients accepting ventriculoperitoneal shunt before bone flap replacement were also excluded from this study. Finally, a total of 13 patients ( 5 male and 8 female) were selected for final analysis.

At the time of surgery, all 13 patients had consciousness deterioration or clinical symptom/sign of increased ICP not respond to medical therapy with obvious mass effect on brain-CT scans. Besides DC, 11 patients accepted additional external ventricular drainage and the other two patients received intra-parenchymal ICP monitor insertion.

After surgery, all patients were monitored in the intensive care unit with ICP-targeted therapy. Cranioplasty was performed under the stabilized clinical condition accompanied with subsided cerebral swelling. Permanent CSF diversion was indicated for patient having persisted radiographic ventricular dilatation after bone flap placement with concomitant worsening neurological expression or lack of clinical improvement.

\section{Definition of Ventricular Dilatation}

In this study, the radiographic evidence of ventricular dilatation, expression as modified Evans index - the ratio of maximum width of the frontal horn to the maximum width of the inner table of the cranium recorded on the side contralateral to the DC, was recorded (Figure 1). This modification was used to avoid calculation bias secondary to post-infarction encephalomalasia. Extra-axial cerebrospinal fluid (CSF) accumulation was defined as low density fluid collection greater than $1 \mathrm{~cm}$ in maximal depth measured from the cortical surface to the inner aspect of the scalp.

Series of change over ventricular dilatation and level of consciousness, Glasgow Coma Scale (GCS) score, were recorded at four different stages: 1): pre-DC stage; 2): post-DC stage while stabilization; 3): post-cranioplasty stage; 4): postshunt stage (for those with permanent CSF diversion) (Table I) (Figure 2A-H).

Fisher's exact test and nonparametric Mann-Whitney $U$ test were used to investigate the associations between the permanent CSF diversion and following risk variables: 1):gender; 2):age; 3):infarction territory ; 4): laterality of DC; 5):time interval from the clinical diagnosis to $D C ; 6)$ : time interval from the DC to cranioplasty; 7): skull defect volume, estimation by $A B C$ method (22); 8):distance between bone flap edge to midline. Statistical difference was judged to be significant while $p$ value less than 0.05 .

\section{RESULTS}

The demographic data of all patients was summarized in Table I. This study consisted of a total of 13 patients (5 male

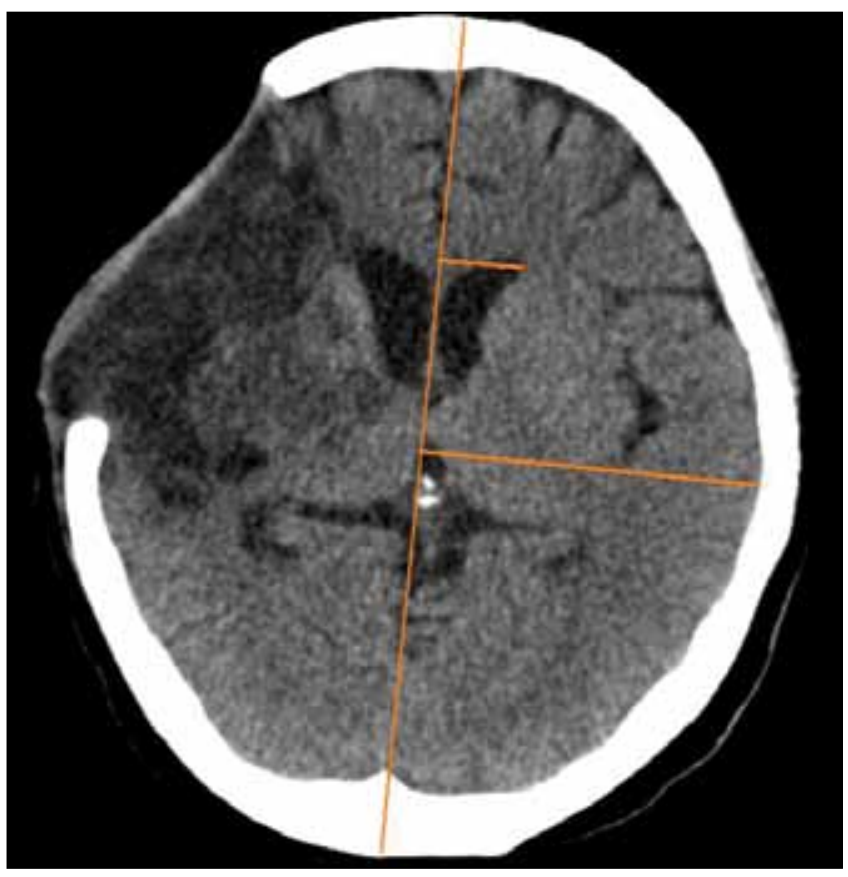

Figure 1: Modified Evans index, the ratio of maximum width of the frontal horn to the maximum width of the inner table of the cranium recorded on the side contralateral to the DC. 
and 8 female) with age ranged from 25 to 84 years (mean, 61.8 years). The involved area of infarction was ICA territory in 6 patients and MCA territory in 7 patients. Ten patients had right-sided and three patients had left-sided infarction. The time interval from clinical diagnosis to DC ranged from 0 to 13 days (mean, 1.84 days). Preoperative GCS score ranged from 5 to 15 , and amount of midline shift ranged from 6.4 to $18.7 \mathrm{~mm}$ (mean, $14.41 \mathrm{~mm}$ ). Skull defect volume ranged from 70.66 to $195.04 \mathrm{~cm}^{3}$ (mean, $108.68 \mathrm{~cm}^{3}$ ) and the distance between bone flap edge to midline was $<25 \mathrm{~mm}$ in 4 patients and $>=$ $25 \mathrm{~mm}$ in 9 patients. The duration from DC to cranioplasty ranged from 21 to 165 days (mean, 75.46 days).

Ventricular dilatation was observed on serial brain CT scans in all 13 patients after DC and extra-axial CSF accumulation developed in two patients. After bone flap placement, the degree of ventricular dilatation did not get recovery in all 13 patients, but extra-axial CSF accumulation in two patients disappeared spontaneously (Figures 2F-G). Four patients accepted permanent CSF diversion under the situations stated above. Among these four patients, all of them did not get improvement over level of consciousness and two of them complicated with subdural effusion (Figure 3F).

The difference of time interval from DC to cranioplasty for patients without and with permanent CSF diversion is not significant (mean: $72.7+/-25.8$, range from 31 to 104 days vs mean:82.7 +/- 63.5 , range from 21 to 165 days; $p=0.668$ ). The mean skull defect volume was $109.9+/-39.7 \mathrm{~cm}^{3}$ (range from 59.95 to $139.77 \mathrm{~cm}^{3}$ ) for patients without permanent CSF diversion and $105.9+/-28.9 \mathrm{~cm}^{3}$ (range from 70.66 to 131.63 $\mathrm{cm}^{3}$ ) for those with permanent CSF diversion $(\mathrm{p}=0.860)$. Three patients $(3 / 9,33 \%)$ got superior edge of bone flap less than 25 $\mathrm{mm}$ from the midline among 9 patients without permanent CSF diversion, and one patient $(1 / 4,25 \%)$ did among 4 patients with permanent CSF diversion. This difference is not significant statistically $(p=0.794)$. The need of permanent CSF diversion was not significantly associated with age, gender, infarction territory, side of infarction and amount of preoperative midline shift respectively (Table II).

\section{DISCUSSION}

Development of hydrocephalus after decompressive craniectomy (DC) was reported by several studies previously, and several identified risk factors had been announced to be responsible for hydrocephalus formation among patients with severe traumatic brain injury (TBI) $(4,6,8,9)$. The direct association between DC itself and hydrocephalus formation is still uncertain, because appearance of variable confounding factors in patients with severe TBI. The significance of post-decompressive hydrocephalus on clinical neurological outcome was discussed only by few reports, because it was believed that persisted hydrocephalus after DC wound make further neurological damage and obstruct clinical improvement. On the other hand, correction of the hydrocephalus should be beneficial for these patients.

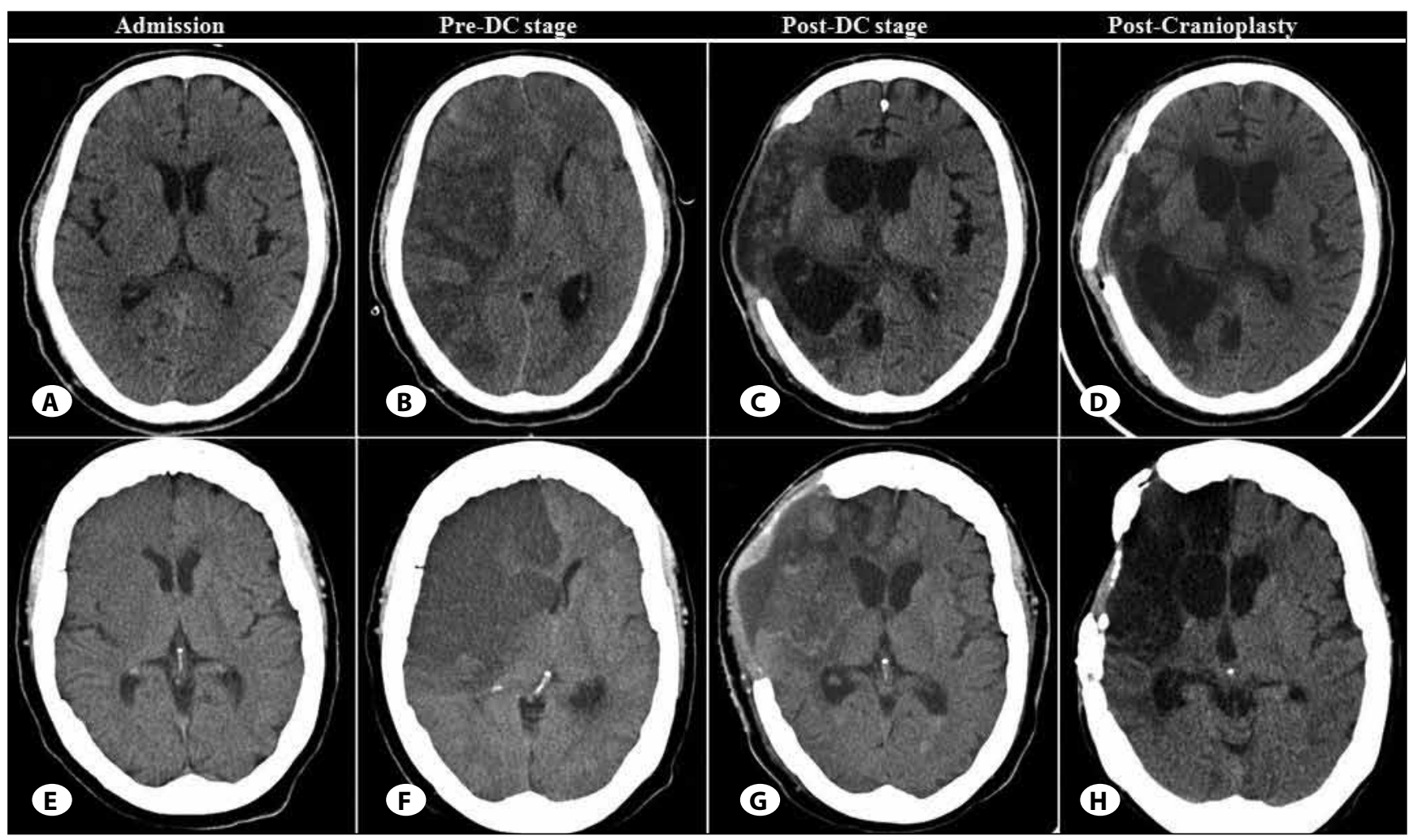

Figure 2: Series of brain-CT scans at different clinical stages for two patients (A-D and E-H) with MCA infarction. They did not accept permanent CSF diversion. 

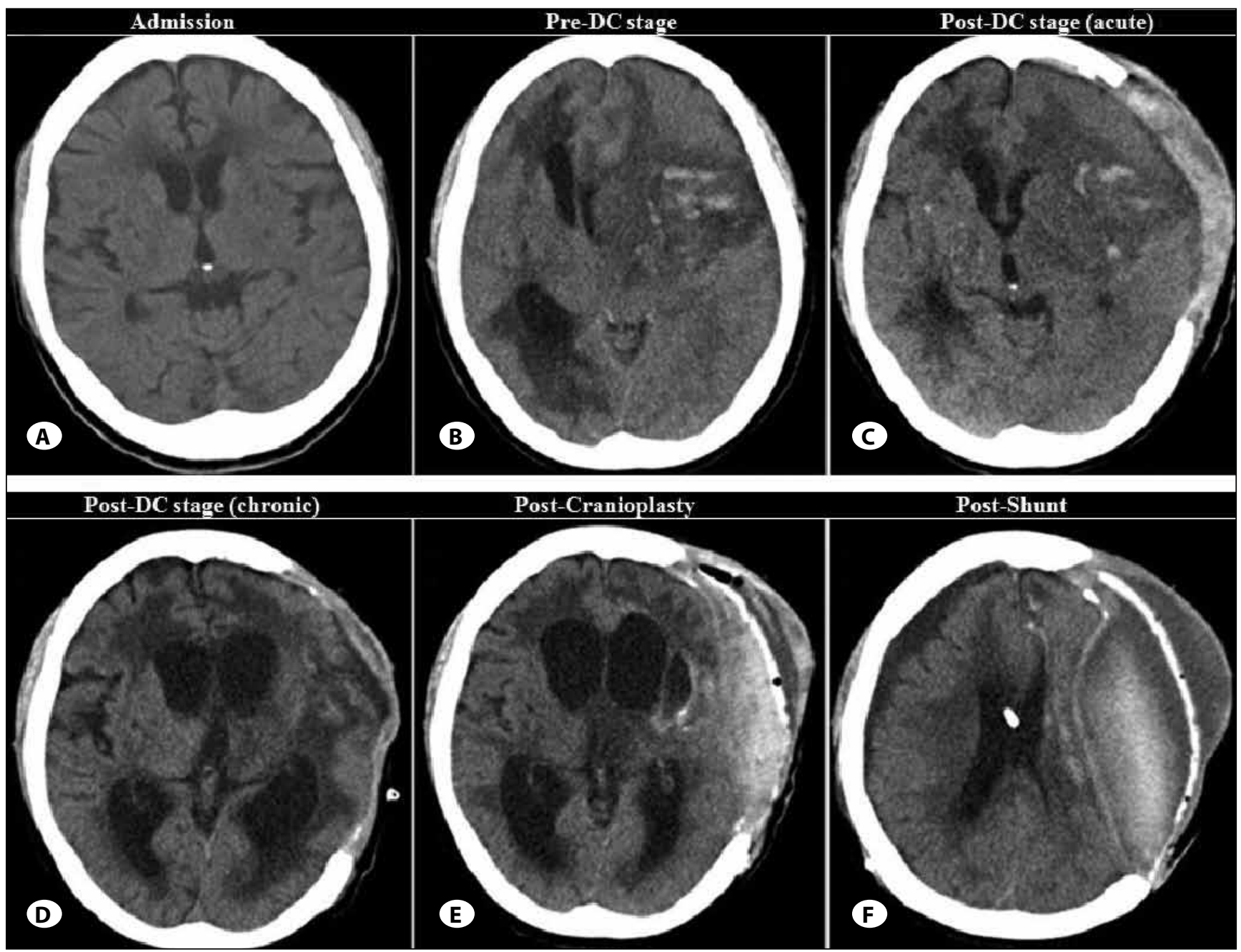

Figure 3: Series of brain-CT scans for one patient with permanent CSF (A-F) diversion.

In recent years there are two studies to report the association between post-decompressive hydrocephalus and clinical neurological expression $(11,15)$. Rahme et al. (15) reported clinically significant hydrocephalus, brain CT finding of hydrocephalus accompanied the worsening in the patient's neurological expression or unexplained lack of neurological improvement, developed in none of 17 patients undergoing DC for cerebrovascular accident (CVA) related refractory elevated ICP. Lee et al. (11) stated that shunt procedure did not significantly improve the clinical condition for 5 patients with persisted CT finding of hydrocephalus among 17 patients accepting DC due to malignant MCA infarction.

In this study, the authors recorded consecutive change of ventricular morphology and level of consciousness at different clinical stage for each patient in order to investigate the relationship between DC and hydrocephalus formation. Previous studies usually defined post-decompressive hydrocephalus as ventricular dilatation with Evans index > 0.3 and narrowed CSF spaces at the convexity on CT scans. These authors claimed that clinical neurological expression was not suitable as component of post-decompressive hydrocephalus evaluation due to appearance of obscure discrimination between initial neurological insult and impact of hydrocephalus for patients with poor neurological status. In our study, sequential change of GCS score instead of the modified Rankin scale was used as clinical assessment at different clinical stage in order to detect subtle difference sensitively.

The consecutive change of GCS score as assessment of clinical neurological outcome is not suitable in some instances. But the authors thought that GCS score is objective and most sensitive to detect subtle neurological deficit for patients with cerebral artery infarction. This is because most of them are functional dependent regardless level of consciousness. Other outcome grading scales descripting independence degree, the modified Rankin scale and the Barthel index, would underestimate the subtle neurological improvement clinically.

All 13 patients in our study got post-decompressive ventricular dilatation comparing with preoperative brain-CT 


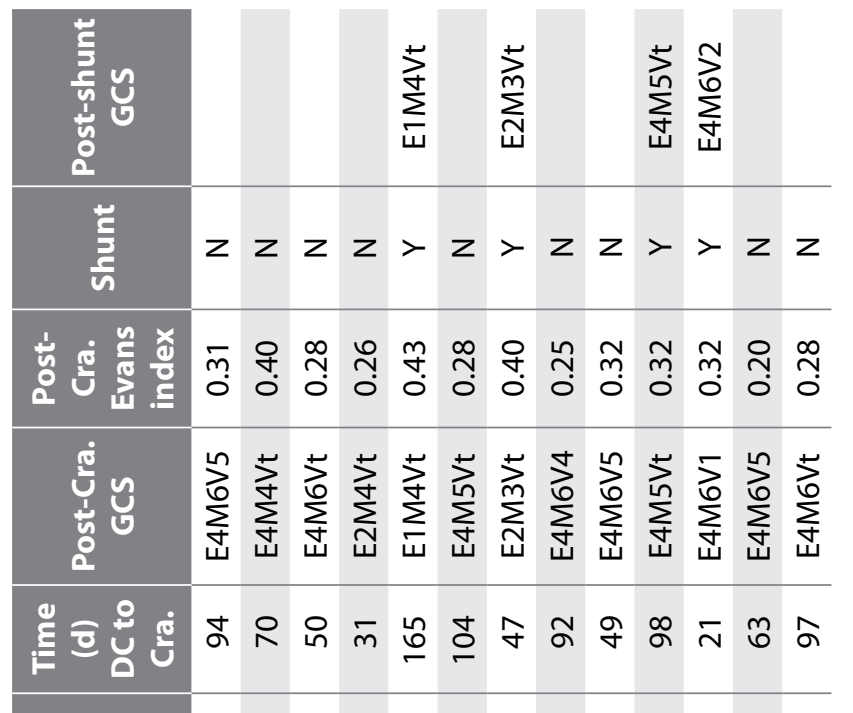

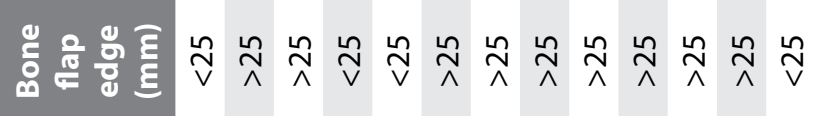

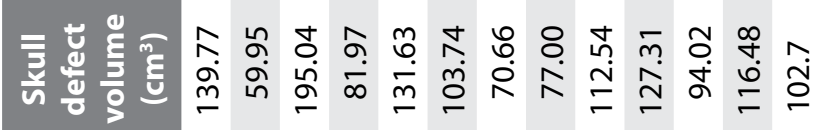

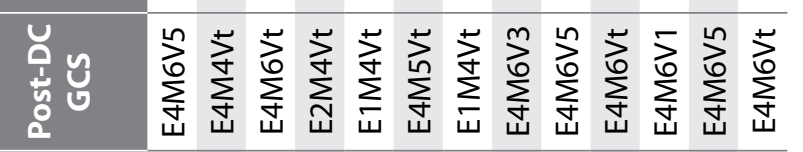

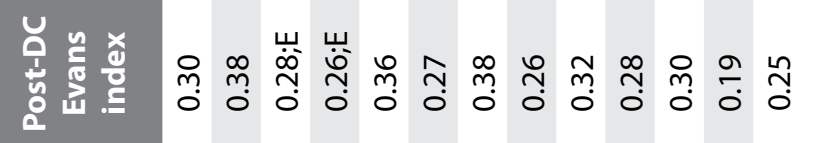

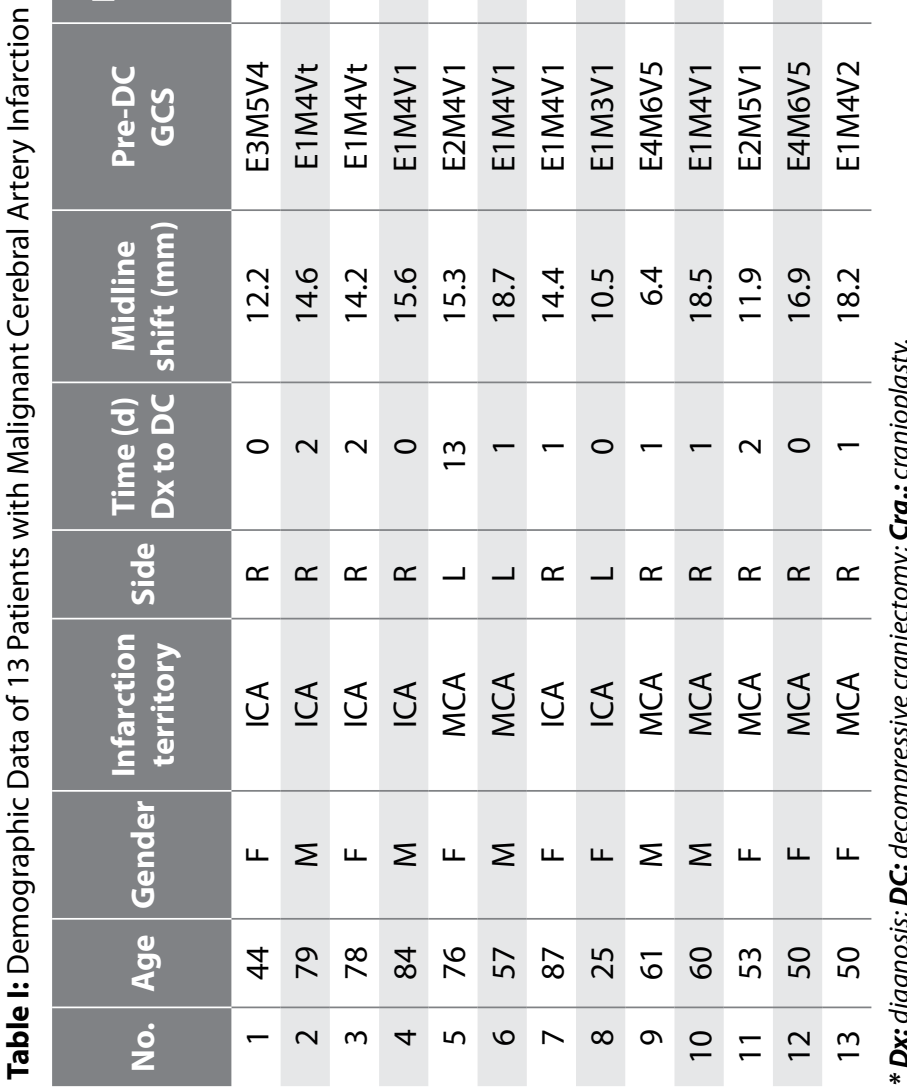

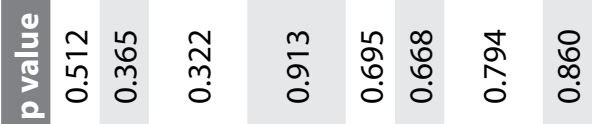

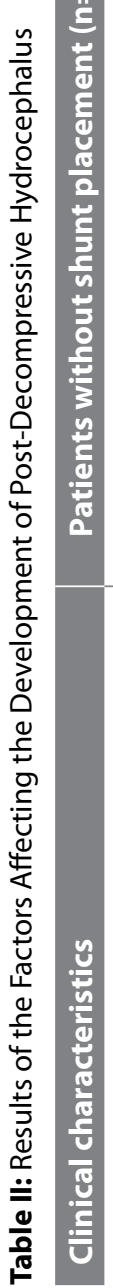


scans. Two of 13 patients got post-decompressive extra-axial CSF collection with disappearance themselves after bone flap placement.

In our study, permanent CSF diversion surgery was done in four patients with persisted ventricular dilatation on serial brain-CT scans and unexplainable neurological deficit after bone flap placement. After shunt placement, there was no obvious improvement of neurological function or level of consciousness over these four patients and two of them complicated with subdural effusion on the side contralateral to the DC. Otherwise, nine patients without CSF diversion surgery showed no recovery of ventriculomegaly on brain $\mathrm{CT}$ scans after bone flap placement.

The definition of post-decompressive hydrocephalus in most studies was made according to image finding, but not ICP measurement or clinical examination.

Management of ventricular dilatation following DC has been a clinical challenge because it is difficult to differentiate asymptomatic ventriculomegaly secondary to atrophic process from a true symptomatic hydrocephalus. Waziri et al. (21) is the first to report that communicating hydrocephalus, defined as radiographic evidence of ventricular dilatation on serial brain-CT scans, is almost a universal finding after hemicraniectomy for patients with ischemic or hemorrhagic stroke (21). It is hypothesized that hemicraniectomy would disturb CSF dynamic flow, and early cranioplasty may lead to recovery of normal CSF dynamics with spontaneous resolution of hydrocephalus. Obviously, the result of our study is not compatible with this hypothesis. In our study, some identified risk factors announced to be responsible for post-traumatic hydrocephalus formation are not significantly different between patients with permanent CSF diversion and those without CSF diversion.

Theoretically, correction of ventriculomegaly should be beneficial to patients with symptomatic hydrocephalus. In our study, modification of ventriculomegaly by permanent CSF diversion surgery not only makes no clinical improvement, the same as Lee's report, but also complicates with overshunting (11).

We audaciously hypothesized that ventricular dilatation after DC is asymptomatic ventriculomegaly, not true symptomatic hydrocephalus. The real mechanism of ventricular dilatation after DC is still unknown. It may be the result of post-infarction encephalomalasia or decreased compliance of ventricle after DC.

This is a retrospective study with small number of patients, and the clinical analysis is based on clinical observation and assessment. In this article, the authors try to evaluate a more pure impact of DC on the development of hydrocephalus. A future prospective study using the ICP measurement and CSF dynamics investigation is required to determine the more appropriate treatment for patients with post-DC ventriculomegaly.

\section{CONCLUSION}

Ventriculomegaly after decompressive craniectomy is a universal radiographic finding on brain-CT scan. The study suggests that ventriculomegaly after DC has no impact on clinical neurological outcome. Permanent CSF diversion makes no clinical improvement with complications of overshunting for this asymptomatic ventriculomegaly after decompressive craniectomy.

\section{REFERENCES}

1. Akins PT, Guppy KH: Sinking skin flaps, paradoxical herniation, and external brain tamponade: A review of decompressive craniectomy management. Neurocrit Care 9:269-276, 2008

2. Ban SP, Son YJ, Yang HJ, Chung YS, Lee SH, Han DH: Analysis of complications following decompressive craniectomy for traumatic brain injury. J Korean Neurosurg Soc 48:244-250, 2010

3. Beauchamp KM, Kashuk J, Moore EE, Bolles G, Rabb C, Seinfeld J, Szentirmai O, Sauaia A: Cranioplasty after postinjury decompressive craniectomy: Is timing of the essence? J Trauma 69:270-274, 2010

4. Choi I, Park HK, Chang JC, Cho SJ, Choi SK, Byun BJ: Clinical factors for the development of posttraumatic hydrocephalus after decompressive craniectomy. J Korean Neurosurg Soc 43:227-231, 2008

5. Danish SF, Barone D, Lega BC, Stein SC: Quality of life after hemicraniectomy for traumatic brain injury in adults. A review of the literature. Neurosurg Focus 26:E2, 2009

6. De Bonis P, Pompucci A, Mangiola A, Rigante L, Anile C: Posttraumatic hydrocephalus after decompressive craniectomy: An underestimated risk factor. J Neurotrauma 27:1965-1970, 2010

7. Guresir E, Schuss P, Vatter H, Raabe A, Seifert V, Beck J: Decompressive craniectomy in subarachnoid hemorrhage. Neurosurg Focus 26:E4, 2009

8. Honeybul S, Ho KM: Incidence and risk factors for post-traumatic hydrocephalus following decompressive craniectomy for intractable intracranial hypertension and evacuation of mass lesions. J Neurotrauma 29:1872-1878, 2012

9. Kaen A, Jimenez-Roldan L, Alday R, Gomez PA, Lagares A, Alen $J F$, Lobato RD: Interhemispheric hygroma after decompressive craniectomy: Does it predict posttraumatic hydrocephalus? J Neurosurg 113:1287-1293, 2010

10. Kontopoulos V, Foroglou N, Patsalas J, Magras J, Foroglou G, Yiannakou-Pephtoulidou M, Sofianos E, Anastassiou H, Tsaoussi G: Decompressive craniectomy for the management of patients with refractory hypertension: Should it be reconsidered? Acta Neurochir (Wien) 144:791-796, 2002

11. Lee $\mathrm{MH}$, Yang JT, Weng HH, Cheng YK, Lin MH, Su CH, Chang CM, Wang TC: Hydrocephalus following decompressive craniectomy for malignant middle cerebral artery infarction. Clin Neurol Neurosurg 114:555-559, 2012

12. Ma L, Liu WG, Sheng HS, Fan J, Hu WW, Chen JS: Decompressive craniectomy in addition to hematoma evacuation improves mortality of patients with spontaneous basal ganglia hemorrhage. J Stroke Cerebrovasc Dis 19:294-298, 2010 
13. Murthy JM, Chowdary GV, Murthy TV, Bhasha PS, Naryanan TJ: Decompressive craniectomy with clot evacuation in large hemispheric hypertensive intracerebral hemorrhage. Neurocrit Care 2:258-262, 2005

14. Olivecrona M, Rodling-Wahlstrom M, Naredi S, Koskinen LO: Effective ICP reduction by decompressive craniectomy in patients with severe traumatic brain injury treated by an ICPtargeted therapy. J Neurotrauma 24:927-935, 2007

15. Rahme R, Weil AG, Sabbagh M, Moumdjian R, Bouthillier A, Bojanowski MW: Decompressive craniectomy is not an independent risk factor for communicating hydrocephalus in patients with increased intracranial pressure. Neurosurgery 67:675-678; discussion 678, 2010

16. Schaller B, Graf R, Sanada Y, Rosner G, Wienhard K, Heiss WD: Hemodynamic and metabolic effects of decompressive hemicraniectomy in normal brain. An experimental PETstudy in cats. Brain Res 982:31-37, 2003

17. Schirmer CM, Hoit DA, Malek AM: Decompressive hemicraniectomy for the treatment of intractable intracranial hypertension after aneurysmal subarachnoid hemorrhage. Stroke 38:987-992, 2007

18. Takeuchi S, Nawashiro H, Wada K, Takasato Y, Masaoka H, Hayakawa T, Nagatani K, Otani N, Osada H, Shima K: Ventriculomegaly after decompressive craniectomy with hematoma evacuation for large hemispheric hypertensive intracerebral hemorrhage. Clin Neurol Neurosurg 115:317322,2013
19. Takeuchi $S$, Takasato $Y$, Masaoka $H$, Hayakawa T, Yatsushige $H$, Nagatani K, Osada H, Otani N, Wada K, Nawashiro H: Hydrocephalus after decompressive craniectomy for hemispheric cerebral infarction. J Clin Neurosci 20:377-382, 2013

20. Vahedi K, Hofmeijer J, Juettler E, Vicaut E, George B, Algra A, Amelink GJ, Schmiedeck P, Schwab S, Rothwell PM, Bousser MG, van der Worp HB, Hacke W: Early decompressive surgery in malignant infarction of the middle cerebral artery: $A$ pooled analysis of three randomised controlled trials. Lancet Neurol 6:215-222, 2007

21. Waziri A, Fusco D, Mayer SA, McKhann GM $2^{\text {nd }}$, Connolly ES, Jr: Postoperative hydrocephalus in patients undergoing decompressive hemicraniectomy for ischemic or hemorrhagic stroke. Neurosurgery 61: 489-493; discussion 493-494, 2007

22. Xiao F, Chiang IJ, Hsieh TM, Huang KC, Tsai YH, Wong JM, Ting HW, Liao CC: Estimating postoperative skull defect volume from $C T$ images using the $A B C$ method. Clin Neurol Neurosurg 114:205-210, 2012

23. Yang XF, Wen L, Shen F, Li G, Lou R, Liu WG, Zhan RY: Surgical complications secondary to decompressive craniectomy in patients with a head injury: A series of 108 consecutive cases. Acta Neurochir (Wien) 150:1241-1247; discussion 1248, 2008 